\title{
Ege Denizi Bağıl Deniz Seviyesi Değişimlerinde Kapula Fonksiyonları İle Trend Analizleri
}

\author{
Ahmet Yavuzdoğan ${ }^{1, \oplus}$, Emine Tanır Kayıkçı \\ ${ }^{1}$ Gümüşhane Üniversitesi, Mühendislik ve Doğa Bilimleri Fakültesi, Harita Mühendisliği Bölümü, 29000, Gümüşhane. \\ ${ }^{2}$ Karadeniz Teknik Üniversitesi, Mühendislik Fakültesi, Harita Mühendisliği Bölümü, 61080, Trabzon.

\section{Özet}

İklim değişikliği başta olmak üzere birçok nedenden dolayı global ölçekte deniz seviyesinde meydana gelen artışlar, kıyı ekosistemlerini etkilemekte ve kıyı yerleşimlerini tehdit etmektedir. Jeodezik açıdan uzun dönemli deniz seviyesi gözlemleri düşey kontrol ağlarının datumunun belirlenmesi açısından önemlidir. Istatistik, ekonomi, aktüerya analizi, meteoroloji, hidroloji gibi birçok alanda farklı değişkenler arasındaki ilişkileri araştırmak için kullanılan Kapula fonksiyonları değişkenlerin ve hatalarının dağılımından etkilenmeyen, lineer ve lineer olmayan ilişkileri yansıtan, lokal bağımlılıkları da gösterebilen korelasyon yapısıyla lineer korelasyon katsayısına göre oldukça elverişli bir korelasyon yapısı sunabilmektedir. Bu çalıșmada, Ege Denizi kıyısında bulunan 5 mareograf istasyonundan elde edilen 1990-2008 yılları arasında aylık deniz seviyesi ve deniz yüzey sıcaklığı ortalamalarl verileri ile kıyllardaki uzun dönemli bağll deniz seviyesi değişimleri ve bu değişimlerin deniz yüzey sicaklı̆̆ ile ilişkisi Kapula Fonksiyonları ile incelenmiştir. Bu çalışma kapsamında ilk defa sunulan kapula temelli trend analiz yöntemi ile deniz seviyesi ve deniz yüzey sicakllğl zaman serilerinde trend analizleri gerçekleștirilerek elde edilen trendler regresyon modelleri ile karșılaștırılmıștır. Ege denizinde 1990-1998 yılları arasında deniz seviyesinin oldukça hızlı bir șekilde arttığl, 1999-2008 yılları arasında ise deniz seviyesinin düștügü görülmüşür. 19901998 yılları arasında deniz seviyelerindeki artışın deniz yüzey sıcaklıklarındaki sıcaklık artışlarından kaynaklandığı, 1999-2008 yılları arasındaki deniz seviyesindeki azalmaların da deniz yüzey sıcaklıklarındaki soğumalardan kaynaklandı̆̆ı değerlendirilmiştir.

\section{Anahtar Sözcükler}

Ege Denizi, Deniz Seviyesi, Mareograf, Korelasyon, Kapula, Trend Analizi, Bağımlılık Modelleme

\section{Trend Analysis of Relative Sea Level Changes in the Aegean Sea with Copula Functions}

\begin{abstract}
Nowadays, it is known that for many reasons such as climate change, the sea level has globally increased. Sea level rises affect coastal ecosystems and threaten coastal settlements. From a geodetic point of view, long term sea level observations are important in terms of determining the datum of vertical control networks. Copula functions, which are frequently used in many fields such as statistics, economics, actuarial analysis, meteorology and hydrology, have a correlation structure that reflects linear and nonlinear relationships and can show local dependencies. In this study, relative sea level changes in the Aegean Sea and the relationship of these changes with sea surface temperature were investigated by using a Copula based trend analysis method. The sea level data used in the study were obtained from 5 tide - gauge stations in the Aegean Sea. Copula based trend analysis was performed in sea level and sea surface temperature time series. The usability of Copula based trend analysis was investigated by comparing it with regression models. As a result, it was observed that although the relative sea level increased rapidly in the Aegean Sea between 1990 and 1998, it decreased between 1999 and 2008. Thanks to the Copula-based trend analysis applied in the sea surface temperature time series, it was observed that the relative sea level rise was caused by the increase in sea surface temperatures between 1990 and 1998. It was determined that sea level decreases between 1999 and 2008 were caused by the decrease in sea surface temperatures.
\end{abstract}

$\underline{\text { Keywords }}$

Aegean Sea, Sea Level, Tide Gauge, Correlation, Copula, Trend Analysis, Dependency Modeling

\section{Giriş}

Günümüzde iklim değişikliği nedeniyle doğal yaşam alanları zarar görmektedir. Atmosferdeki sera gazının artması nedeniyle sıcaklıklar artmakta ve artan sicaklıklar yeryüzünde deniz ve okyanus sularının genleșmesine, buzulların erimesine ve yağış rejimlerinin düzensizleşmesine sebep olmaktadır (Demir 2018). Deniz ve okyanus sularındaki artışlar kıyılardaki doğal yaşam alanlarını tehdit etmekte, taşkınlara, kıyılara yakın arazilerin sular altında kalmasına sebep olmaktadır. Deniz seviyesi verileri, klimatoloji ve kıyı mühendisliği açısından önemli olmasının dışında düşey kontrol ağlarının datumu açısından Jeodezi biliminde büyük önem arz etmektedir. 
Ortalama deniz seviyesi uzun yıllar boyunca değişmeyen bir yüzey olarak kabul edilmiş ve düşey kontrol ağlarının datumu olarak kullanılmıştır. Ancak geçen yüzyılda global deniz ve okyanus seviyesindeki yüksek artış hızları deniz seviyesinin beklenildiği gibi değişmeyen bir yüzey olmadığını ortaya çıkarmıştır (Hannah 1989; Simav 2007). Böylece aslında jeodezik olarak da düşey kontrol ağlarının datumunun güncellenmesi sorunu da ortaya çıkmaktadır. Bu nedenlerle deniz seviyesi değişimlerinin izlenmesi ve yorumlanması jeodezi, klimatoloji ve daha birçok bilim dalı için önem arz etmektedir. Literatürde Global ve Bölgesel ölçekte deniz seviyesi değişimlerini belirlemek için birçok çalışma yapılmıştır. Global ölçekte yapılan çalışmalarda; (Church vd. 2004) mareograf istasyonlarına ait deniz seviyesi gözlemlerinin 19502000 yılları arasında yıllık 1.8 mm ile yükseldiği, (Jevrejeva vd. 2014) 1993-2009 yılları arasında global deniz seviyesi değişiminin $3.1 \pm 0.4 \mathrm{~mm} / \mathrm{y} 1$ olduğu, (Hay vd. 2015) 1993-2015 yılları arasındaki global deniz seviyesi değişiminin $3 \pm 0.7$ $\mathrm{mm} / \mathrm{y}$ ıl olduğu ifade edilmiştir. (Cazenave 2017) deniz seviyesi artış hızının yaklaşık olarak $0.08 \mathrm{~mm} / \mathrm{y}_{1}{ }^{2}$ pozitif bir ivmeye sahip olduğunu, deniz seviyesi artışlarının \%42 artan deniz suyu sıcaklığından kaynaklı 1sıl genleşmeye, \%44 buzulların erimesine ve \%14 diğer etkenlere bağlı olduğunu ifade etmiştir. Yapılan bu çalışmalardan, global deniz seviyesinin 1900'lü yıllardan itibaren arttığı, 1900'den 2000'e kadar deniz seviyesi artış hızının 1-2 mm/yıl seviyesinde olduğu ancak 1997' den günümüze kadar deniz seviyesi artış hızının 3-3.3 mm/yıl seviyelerine ulaştığı anlaşılmaktadır. Global ölçekte deniz seviyesinin artmakta olduğu ve bu artış hızının da yine pozitif bir ivmeye sahip olduğu görülmektedir. Bu çalışmalarda deniz seviyesi artış hızlarının nedeni olarak büyük oranda sıcaklık artışlarına bağlı deniz suyu genleşmesi ve buzulların erimesi gösterilmektedir. Bu çalışmanın uygulandığı Ege Denizi literatürde genellikle Akdeniz içerisinde bir bölge olarak çalışılmaktadır. Ege ve Akdeniz'de yapılan bölgesel ölçekteki çalışmalarda ise; Tsimplis ve Baker (2000) Akdeniz'de deniz seviyesi değişimlerini 1910-1960 ve 1960-1990 olarak iki farklı dönemde incelenmiş ve Akdeniz'de deniz seviyesinin 1910-1960 yılları arasında yıllık 1.2-1.5 mm artış hızına sahip olduğunu, 1960-1990 arasında deniz seviyesinin yıllık -1.3 mm hız ile azaldığını, bu değişimlerin 1960-1990 yılları arasındaki deniz suyu sıcaklığının azalması nedeniyle ortaya çıktığını ifade etmiştir (Cazenave vd. 2001; 2002). 1993-1999 yılı arasındaki Akdeniz bölgesinde deniz seviyesi değişimlerini inceledikleri çalışmada, Ege Denizi ve Akdeniz'de deniz seviyesinin arttığı belirlenmiş ve bu artış miktarları ile deniz yüzey sıcaklıkları arasında yüksek bir korelasyonun olduğu görülmüştür. Deniz seviyesindeki değişimlerin sebebinin deniz yüzey sıcaklıklarındaki değişimler olabileceği ifade edilmiştir. Literatürde genellikle deniz seviyesi değişimleri ve bu değişimlerin nedenleri birçok araştırmacı tarafından lineer korelasyon katsayıları ve buna dayalı yöntemler ile araştırılmaktadır. Ancak lineer korelasyon yöntemleri değişkenler arasındaki ilişkilerin doğrusal olduğunu ve hata terimlerinin dağılımının normal olduğunu varsaymaktadır. Sadece bu koşullar altında bağımlılıkları modellemek için uygun bir model sunabilir. Yüksek kuyruk dağılımına sahip değişkenlerde, değişkenlerin varyansları sonsuza yakınsayabilir. $\mathrm{Bu}$ nedenle korelasyon katsayıları tanımlanamaz. Bununla beraber deniz seviyesi değişimleri ile ilgili değişkenler ve hataları genellikle normal dağılımda olmadığından lineer korelasyon yöntemlerinin uygulanması doğru değildir. Bu amaçla gerçekleştirilen çalışmada, deniz seviyesi değişimleri ve değişimlerinin deniz yüzey sıcaklığı ile ilişkisi değişkenlerin ve hatalarının dağılımlarından etkilenmeyen, lokal (kuyruk) bağımlılıklarını yansıtan hem lineer hem de lineer olmayan ilişkileri modelleyebilen kapula fonksiyonları ile araştırılması amaçlanmaktadır. Kapula fonksiyonları her ne kadar değişkenler arasındaki ilişkinin yönünü ve miktarını gösterse de geleceğe yönelik yapılacak tahmin çalışmalarında oldukça karmaşık bir yapı sunmaktadır. Bu nedenle zaman serilerinde sıklıkla kullanılan trend analizlerinin kapula fonksiyonları ile yapılması amacıyla Arşimedyen kapula bağımlılık modelleri kullanılarak trend olasılıklarının simülasyonuna dayanan yeni bir kapula temelli trend analiz yöntemi sunulmuştur. Bu kapula temelli trend analiz yöntemi ilk olarak Ege Denizi'nde bulunan 5 Mareograf istasyonundan elde edilen 1990-2008 aralığındaki aylık ortalamalı deniz seviyesi zaman serilerinde uygulanmış, ardından deniz seviyelerinde oluşan farklılıkların incelenmesi amacıyla zaman serilerinde 1990-1998 (1. Dönem) ve 1999-2008 (2. Dönem) olmak üzere iki farklı dönemde kapula temelli trend analizleri yapılmıştır. Deniz seviyesi değişimlerinde meydana gelen farklılıkların nedenlerinin araştırılması amacıyla deniz yüzey sıcaklığı zaman serileri de aynı şekilde 1990-1998 ve 19992008 olmak üzere iki farklı dönemde kapula temelli trend analizleri ile incelenmiştir.

\section{Yöntem}

Kapula fonksiyonları, tek değişkenli dağılım fonksiyonlarını ortak dağılıma bağlayan fonksiyonlardır (Sklar 1959) (Şekil 1). Ĕ̆ger değişkenlere ait marjinal dağılımlar biliniyorsa, değişkenlerin ortak dağılımı kapula fonksiyonları kullanılarak oluşturulabilir. Kapula fonksiyonları Biyomedikal, Hidroloji, Klimatoloji, Hidro-Jeodezi gibi alanlarda çok değişkenli bağımlılık yapılarının incelenmesinde, parametrik olmayan bağımlılık ölçütlerinin geliştirilmesinde, stokastik modelleme çalışmalarında sıklıkla kullanılmaktadır (Wang ve Wells 2000; Bárdossy ve Li 2008; Vogl vd. 2012; Modiri 2015; Özbakış 2006; Laux vd. 2012). 


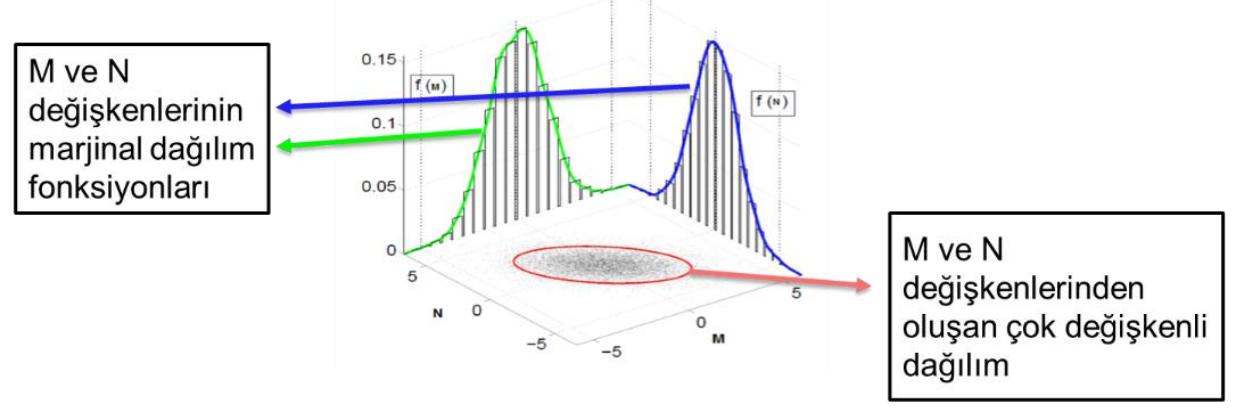

Şekil 1: Íki değişkenli durumda Marjinal dağılım fonksiyonları ve ortak dağılım (Modiri 2015)

İlk defa 1959’da Sklar tarafından literatüre kazandırılan Sklar Teoremi’ne göre çok değişkenli bir dağılım;

$$
H(x, y)=C(F(x), G(y))
$$

değişkenlerin kendi dağılımları (Marjinal dağılım) ve kapula fonksiyonu ile oluşturulabilir. Burada $F(x)$ ve $G(y) x$ ve $y$ değişkenlerine ait dağılım fonksiyonlarını, $H(x, y)$ ise dağılım fonksiyonları $F(x)$ ve $G(y)$ olan ortak dağılımdır. Burada $C$ ise $F(x)$ ve $G(y)$ dağılımlarını $H(x, y)$ ortak dağılımına bağlayan fonksiyondur ve kapula fonksiyonu olarak tanımlanır.

\subsection{Arşimedyen Kapula Fonksiyonları}

Arşimedyen kapula fonksiyonları pozitif ve negatif bağımlılıkları modelleyebilmesi, tek üretici fonksiyon yardımıyla kolayca türetilebilmesi, lokal (kuyruk) bağımlılıklarını yansıtabilmesi gibi özellikleri nedeniyle değişkenler arasındaki bağımlılık yapılarının modellenmesinde sıklıkla kullanılmaktadır (Topçu 2013). Kapula üretici fonksiyon, Sklar Teoremi ile Arşimedyen kapula fonksiyonunun üretilmesini sağlayan fonksiyonlardır (Çelebioğlu 2003). Bu çalışmada kullanılan Arşimedyen kapula fonksiyonları Clayton, Frank ve Gumbel kapula fonksiyonlarıdır (Şekil 2).
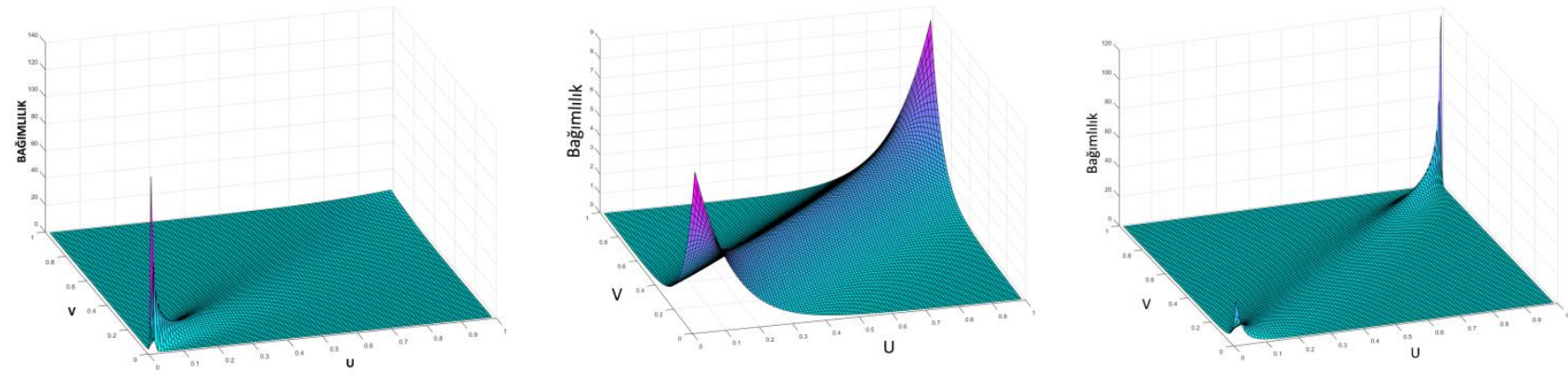

Şekil 2: Sırasıyla Clayton, Frank ve Gumbel kapula fonksiyonları

Şekil 2'de verilen u ve v değerleri değişkenlere ait marjinal dağılımları göstermektedir. Dolayısıyla kapula fonksiyonları değişkenlerin marjinal dağılımları arasındaki bağımlılık ilişkisini kuran fonksiyonlar olarak tanımlanabilir (Şekil 3). Bu çalışmada u ve v değerleri deniz seviyesi ve zaman değişkenlerine ait marjinal olasılık dağılımlarını göstermektedir.
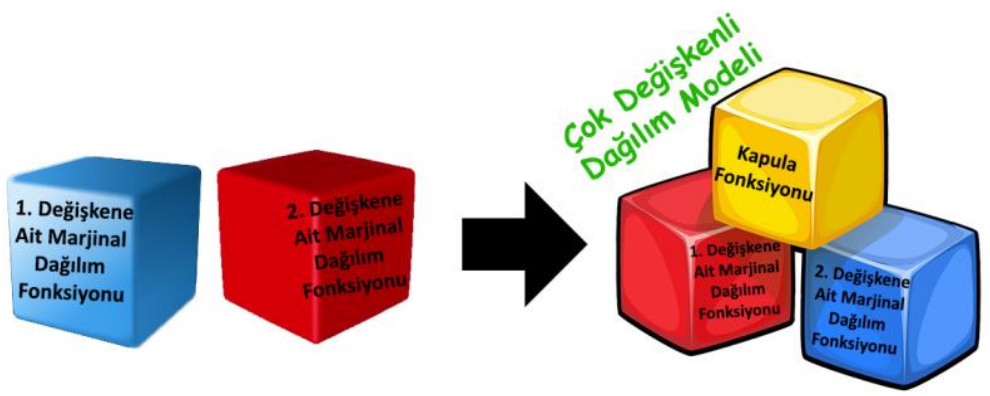

Şekil 3: Marjinal dağılımlar ve kapula fonksiyonları ile çok değişkenli dağıım 


\subsubsection{Clayton Kapula Fonksiyonu}

Clayton kapula fonksiyonu pozitif yöndeki bağımlılıkları modelleyebilmekte ve sol kuyruk bağımlılıklarını yansıtabilmektedir. Clayton kapula fonksiyonu ile modellenebilen gözlemlerde küçük değerler arasındaki pozitif korelasyonlar büyük değerlere göre daha fazladır. Clayton kapula fonksiyonuna ait kapula üretici fonksiyon,

$$
\varphi(t)=\frac{1}{\theta}\left(t^{-\theta}-1\right)
$$

şeklinde yazılır. Clayton kapula fonksiyonu,

$$
C_{\theta}(u, v)=\max \left[\left(u^{-\theta}+v^{-\theta}-1\right), 0\right]^{\left(\frac{-1}{\theta}\right)}
$$

olarak tanımlanır. $\theta$ kapula parametresi olup $[-1, \infty)$ aralığındadır. $\theta=0$ durumunda değişkenler bağımsızdır (Joe 1997).

\subsubsection{Frank Kapula Fonksiyonu}

Kuyruklarda simetrik bir yapıya sahip olan Frank kapula fonksiyonu pozitif ve negatif yöndeki bağımlılıkları modelleyebilmektedir. Ancak kuyruk bağımlılıklarını yansıtmaz. Frank kapula fonksiyonuna ait kapula üretici fonksiyon,

$$
\varphi(t)=-\ln \left\{\frac{e^{-\theta t}-1}{e^{-\theta}-1}\right\}
$$

şeklinde tanımlanır. Kapula fonksiyonu ise,

$$
C_{\theta}(u, v)=\frac{1}{\theta} \ln \left(1+\frac{\left(e^{-\theta u}-1\right)\left(e^{-\theta v}-1\right)}{e^{-\theta}-1}\right)
$$
2007).

olarak tanımlanır. $\theta$ kapula parametresi $(-\infty, \infty)$ aralığındadır. 0 ise tam bağımsızlık durumunu göstermektedir (Nelsen

\subsubsection{Gumbel Kapula Fonksiyonu}

Pozitif yöndeki bağımlılıkları modelleyebilen Gumbel kapula fonksiyonu aynı zamanda alt kuyruktaki bağımlılıkları yansıtmada oldukça kullanışlı bir yapıya sahiptir. Gumbel kapula fonksiyonu kullanılarak modellenebilen gözlemler büyük değerlerde küçük değerlere göre daha yüksek korelasyona sahip gözlemlerdir. Gumbel kapula fonksiyonuna ait kapula üretici fonksiyon,

$$
\varphi(t)=(-\ln t)^{\theta}
$$

şeklinde tanımlanır. Kapula fonksiyonu ise,

$$
C_{\theta}(u, v)=e^{-\left(\left(-\ln (u)^{\theta}\right)+\left(-\ln (v)^{\theta}\right)\right)^{1 / \theta}}
$$

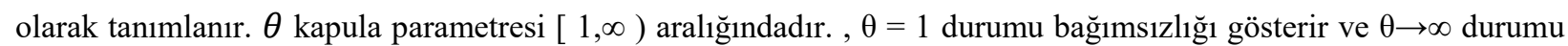
ise güçlü pozitif bağımlılığı göstermektedir (Nelsen 2007).

\subsection{Deneysel Kapula}

Deneysel kapula fonksiyonu veri setinin tüm bağımlılık yapısını yansıttığı varsayılan bilinmeyen teorik kapula dağılımları için bir tahmin edici fonksiyondur. Deneysel kapula;

$$
C_{e}(u, v)=\frac{1}{n} \sum_{i=1}^{n} 1\left(\frac{r_{i}}{n+1} \leq u, \frac{s_{i}}{n+1} \leq v\right)
$$

formülü ile hesaplanır. Burada 1 başlatıcı fonksiyondur. Eğer koşul doğruysa 1, yanlış ise 0' a eşittir. $r_{i}$ ve $s_{i}$ verilerin sıralarının çiftlerini göstermektedir. $\mathrm{n}$ ise veri sayısıdır. Deneysel kapula fonksiyonu verilerin sıra uzayındaki yoğunluğunu göstermektedir (Genest ve Favre 2007). İki değişkenli durumda sıra uzayı değişkenlerin küçükten büyüğe doğru sıra numaralarının [0,1] aralığında normlandırılması ile elde edilen uzaydır. Sıra uzayı ve bu uzayın yoğunluğunu gösteren deneysel kapula fonksiyonu verilerin korelasyon yapısını göstermesi nedeniyle oldukça önemlidir. 
Örneğin normal dağılıma sahip iki değişkenli durumda doğrusal (Pearson) korelasyon katsayısı $\rho=1, \rho=0.90$ ve $\rho=40$ için verilerin sıra uzayı ve deneysel kapula fonksiyonu Şekil 4’teki gibidir.
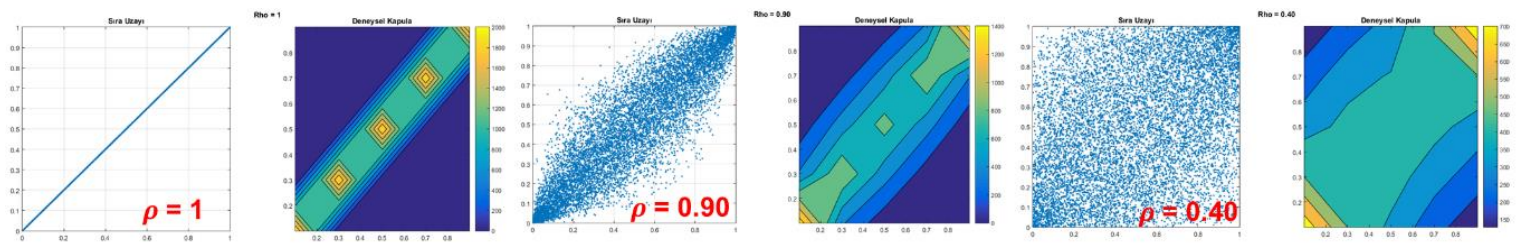

Şekil 4: Normal dağılımda farklı korelasyon katsayılarında deneysel kapulalar

$\rho=1$ için Şekil 4 incelenecek olursa tam bağımlılık durumunda, birinci değişkene ait küçük veri değerlerine karşılık ikinci değerlerde küçük değerler ve birinci değişkene ait büyük veri değerlerine karş̧lık büyük değerler olduğu görülmektedir. $\mathrm{Bu}$ nedenle tam pozitif bağımlılık durumunda sıra uzayı $\mathrm{y}=\mathrm{x}$ diagonalinde tam bir doğru halini almaktadır. Ayrıca korelasyon miktarı düştüğünde ( $\rho=0.90$ ve $\rho=40$ için) birinci değişkene ait küçük değerlere karşlık ikinci değişkende hem büyük hem de küçük değerler olduğu ve sıra uzayının diyagonalden uzaklaştığı görülmektedir. Benzer şekilde eğer negatif korelasyon varsa verilerin sıra uzayı ve deneysel kapulaları $\mathrm{y}=-\mathrm{x}$ diagonalinde yoğunlaşmaktadır.

\subsection{Kapula Parametresi Tahmini}

Kapula parametresi her kapula fonksiyonu için farklı değer aralıklarına sahip olan ve değişkenler arasındaki bağımlılığı gösteren bir katsayıdır. Bu katsayı hem bağımlılığın yönünü hem de bağımlılığın miktarını göstermesi açısından önemlidir. Ayrıca kapula üretici fonksiyonlarda yer alır. Bu parametrenin tahmini için parametrik ve parametrik olmayan birçok tahmin yöntemi vardır. Bu çalışmada parametrik yöntemlerden maksimum olabilirlik yöntemi (Maximum Likelihood) kullanılmıştır. $C(u, v)$ kapula fonksiyonu olmak üzere kapula fonksiyonuna ait yoğunluk fonksiyonu,

$$
c(u, v)=\frac{\partial c(u, v)}{\partial u \partial v}
$$

formülü ile hesaplanır. Örnek veri seti $X=\left\{x_{1 t}, x_{2 t}, x_{3 t}, \ldots x_{n t}\right\}_{t=1}^{T}$ olsun. Bu durumda log-olabilirlik fonksiyonu,

$$
l(\theta)=\sum_{i=1}^{T} \log \left\{c\left(F_{1}\left(x_{1 t}\right), F_{2}\left(x_{2 t}\right) \ldots F_{n}\left(x_{n t}\right)\right)\right\}+\sum_{t=1}^{T} \sum_{j=1}^{n} \log f j\left(x_{j t}\right)
$$

olarak tanımlanır. Burada T veri boyutunu, F marjinal dağılım fonksiyonunu, $\theta$ marjinal dağılımlara ve kapula fonksiyonuna ait parametreler vektörünü göstermektedir. maksimum olabilirlik yöntemi ile kapula parametresi;

$$
\theta_{M L E}=\max (l(\theta))
$$

olarak hesaplanır (Bingöl 2012).

\subsection{Uyum İyiliği Testi}

Kapula fonksiyonları ile bağımlılıklar modellenirken değişkenler arasındaki ilişkiyi en iyi yansıtacak teorik kapula fonksiyonu Uyum İyiliği Testi (Goodness of Fit Test) ile seçilir (Nelsen 2007). Uyum iyiliği testinde deneysel kapula fonksiyonunun değişkenler arasındaki bağımlılığı tamamen içerdiği kabul edilerek, deneysel kapula fonksiyonuna en yakın teorik kapula fonksiyonunun seçilmesi amaçlanır. Çok değişkenli dağılıma ait deneysel kapula ve teorik kapula fonksiyonlarının hesaplanmasının ardından bağımlılığı en iyi modelleyecek kapula fonksiyonu Cramer - Von Mises Metriği ile belirlenir. Uyum iyiliği testinin ilk aşamasında değişkenlere ait değerler sıra uzayında normlandırılarak sözde gözlem değerleri (w) elde edilir. Sözde gözlem değerleri,

$$
Z_{i}=\frac{\sum_{j=1}^{n}\left[I\left\{X_{j} \leq X_{i} \wedge Y_{j} \leq Y_{i}\right\}\right]}{n+1}
$$

eşitliği ile elde edilir. Sözde gözlem değerleri, değişkenlere ait dağılım fonksiyonu değerleri ile karşılaştırılarak tek boyutta deneysel kapula fonksiyonu,

$$
K_{n}(z)=\frac{\sum_{j=1}^{n} I\left[\left\{z_{j} \leq z\right\}\right]}{n+1}
$$


$K_{n}(z)$ elde edilir. Burada I birim (identity) matris, yani z değerlerinin $Z_{j}$ değerlerinden küçük olduğunda 1 olmadığında 0 değerini alan matristir. Tek boyutta teorik kapula fonksiyonu $K_{\emptyset}(z)$ ise,

$$
K_{\emptyset}(z)=z-\frac{\phi(z)}{\phi^{\prime}(z)}
$$

formülü ile elde edilir. Burada $\phi$ kapula üretici fonksiyonu $\phi^{\prime}$ ise kapula üretici fonksiyonun türevini göstermektedir. Deneysel ve teorik kapula fonksiyonunun tek boyutta elde edilmesinin ardından deneysel kapula ile teorik kapula fonksiyonu arasındaki kare uzaklık olan Cramer - Von Mises metriği,

$$
V=\sum\left[K_{\phi}(z)-K_{n}(z)\right]^{2}
$$

ile hesaplanır. Burada $K_{\phi}(z)$ tek boyutta deneysel kapulayı, $K_{n}(z)$ ise tek boyutta teorik kapula fonksiyonunu ifade etmektedir (Topçu 2013).

\subsection{Koşullu Kapula Fonksiyonları}

Koşullu kapula fonksiyonları değişkenlere ait dağılımlar ile ortak dağılımların oluşturulmasında kullanılan fonksiyonlardır. Koşullu kapula fonksiyonları aslında koşullu bayes teoremine dayanmakta ve girilen veri olasılıkları ile ortak dağılıma ait veri olasılıkları elde edilebilmektedir. Veri olasılıkları ters marjinal dönüşümler ile gerçek veri değerlerine dönüştürülebilir. Clayton, Frank ve Gumbel kapula fonksiyonlarına ait koşullu kapula formülleri sırasıyla;

$$
\begin{aligned}
& C_{V=v}^{\text {Clayton }}(u, v)=u^{-\theta-1}\left(-1+u^{-\theta}+v^{-\theta}\right)^{\left(\frac{-1}{\theta}-1\right)} \\
& C_{V=v}^{F r a n k}(u, v)=\frac{e^{-u \theta}\left(-1+e^{-v \theta}\right)}{\left(-1+e^{-\theta}\right)\left(1+\frac{\left(-1+e^{-u \theta}\right)\left(-1+e^{-v \theta}\right)}{-1+e-\theta}\right)} \\
& C_{V=v}^{G u m b e l}(u, v)=\frac{\left(-\ln u^{\theta-1}\right)\left(\operatorname{lnv}\left(\theta-\ln v^{\theta}\right)^{\left(\frac{1}{\theta}-1\right)}\right)}{u e\left(-\ln u^{\left.\left(\theta+\ln v^{\theta}\right)^{\left(\frac{1}{\theta}\right)}\right)}\right.}
\end{aligned}
$$

olarak yazılır (Joe 1997).

\subsection{Arşimedyen Kapula Fonksiyonları ile Trend Analizi}

Zamana bağlı bir değişken hakkında elde edilen gözlem değerlerinin, uzun zaman aralığında artma veya azalma yönünde gösterdiği eğilime "trend" denir (Beşel ve Kayıkçı 2016). Zaman serilerinde trend değerleri serinin eğilimini gösteren ortalama değerler olarak düşünülebilir. Trend, serinin uzun dönem içerisinde gösterdiği eğilimi yansıtması açısından oldukça önemlidir. Kapula fonksiyonları ise değişkenlere ait bağımlılıkları yansıtan ve veri olasılıkları ile çok değişkenli dağılımları oluşturabilen kompleks bir modeldir. Bu kompleks modelde yer alan kapula parametresi ile değişkenler arasındaki ilişkinin yönü ve bağımlılık miktarı görülebilse de, trend analizi için yeterli değildir. Bu çalışmada ilk defa sunulan Arşimedyen kapula fonksiyonları ile trend analiz yaklaşımında, trend değerleri koşullu kapula fonksiyonları kullanılarak üretilmiştir. Koşullu kapula fonksiyonları aslında Bayes teoremine dayanmaktadır ve değişkenlere ait dağılımların (olasılıkların) bilinmesi gerekmektedir. Verilere ait dağılımlar herhangi teorik bir dağılım tarafından modellense bile geleceğe yönelik değerlerin hangi dağılıma yakınsayacağı tam olarak bilinemeyebilir. Bu nedenle trend analizi yapılırken değişkenlere ait marjinal dağılımların etkisi giderilerek ortalama değerler elde edilmelidir. Bu yöntemde temel mantık ortak dağılımdan değişkenlerin dağılımların etkisinin giderilmesi ve değişkenler arasındaki bağımlılık yapısına en uygun teorik kapula fonksiyonunun koşullu dağılımı ile değiş̧enler arasındaki eğilimlerin ortaya çıkarılmasıdır. Bu yaklaşımda değişkenlerin dağılımlarının etkisinin giderilmesi için değişkenlere ait dağılımlar tekdüze (uniform) olarak seçilmiştir. Zaman serilerinde yapılacak trend analizlerinde bağımsız değişkene ait dağılım zaten tekdüzedir. Bağımlı değişkene ait dağılım ise 0.5 olasılık değerinde tekdüze bir dağılım yapısında seçilir. Çünkü veri olasılıkları 0 ile 1 arasında değişmektedir. 0.5 değeri ise olasılık uzayının tam ortasında yer almakta ve ortalama değerlerin olasılığını göstermektedir. Böylece değişkenlerin dağılımlarının etkisi giderilmiş olur. Bu veri olasılıkları verinin bağımlılık modelinde yer alan teorik kapula fonksiyonunun koşullu dağılım formülü ile trend olasıllık değerlerine dönüştürülür. Elde edilen trend olasılıkları ters marjinal dönüşümler ile trend değerlerine dönüştürülerek zaman serisine ait trend elde edilir (Şekil 5). 


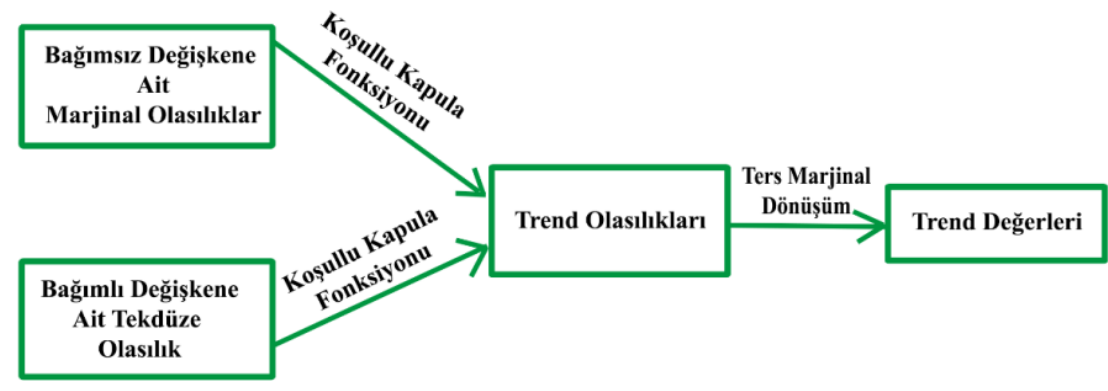

Şekil 5: Arşimedyen kapula fonksiyonları ile trend analizi işlem adımları

Kapula temelli trend analizinin ilk aşaması zaman serisindeki değişkenlere ait deneysel birikimli dağılımların teorik bir dağılım fonksiyonu ile modellenmesi işlemidir. Değişkenlerin deneysel dağılımları kullanılarak teorik dağılım fonksiyonu ve bu fonksiyona ait parametrelerin bulunması işlemi esasında bir dağılım uydurma (Distribution Fitting) işlemidir. Dağılım uydurma, bir popülasyona ait örnek veriler üzerinden popülasyonun ait olduğu dağılımı ve bu dağılıma ait parametreleri tahmin etme ișlemidir. Burada teorik birikimli dağılım fonksiyonlarına ait parametreler maksimum olabilirlik yöntemi (Maximum Likelihood Estimation) ile tahmin edilmiştir. Örneğin $X_{1}, X_{2}, X_{3}, \ldots, X_{n}$ bir popülasyondan alınan birbirinden bağımsız örnek veriler olsun. maksimum olabilirlik yöntemi ile tahmin edilecek dağılım parametreleri $\theta_{1}, \theta_{2}, \theta_{3}, \ldots, \theta_{\mathrm{n}}$ olsun. Dağılıma ait olasılık yoğunluk fonksiyonu,

$$
f\left(x_{i} ; \theta_{1}, \theta_{2}, \theta_{3}, \ldots, \theta_{n}\right)
$$

olarak yazılır. Burada x verileri, $\theta_{1}, \theta_{2}, \theta_{3}, \ldots, \theta_{\mathrm{n}}$ dağılım parametrelerini göstermektedir. Örneğin Normal Dağılım için tahmin edilecek parametreler $\mu$ ortalama ve $\sigma^{2}$ varyans parametreleridir. Olabilirlik fonksiyonu,

$$
L=\prod_{i=1}^{n} f\left(x_{i} ; \theta_{1}, \theta_{2}, \theta_{3}, \ldots, \theta_{n}\right)
$$

şeklinde yazılır (Harris ve Stöcker 1998). Burada n veri sayısıdır. Olabilirlik fonksiyonunun doğal logaritması alınarak log-olabilirlik fonksiyonu,

$$
\ln L=\sum_{i=1}^{n} \ln f\left(x_{i} ; \theta_{1}, \theta_{2}, \theta_{3}, \ldots, \theta_{n}\right)
$$

olarak bulunur (Harris ve Stöcker 1998). Log-olabilirlik fonksiyonunu maksimum yapan değer maksimum olabilirlik tahmin edici değeridir. Burada log-olabilirlik fonksiyonu en büyük yapan değeri bulmak için bulunmak istenen parametreye göre log-olabilirlik fonksiyonunun türevi alınarak denklem 0’a eşitlenir. Böylece denklemlerin çözümünden maksimum olabilirlik yöntemi ile dağılım parametreleri bulunur.

Örneğin, 12 y1l 6 ay uzunluğunda, aylık ortalamalı, 150 elemanlı bir deniz seviyesi zaman serisi olsun. Zaman değerleri ayları temsil eden $\{1,2,3, \ldots, 150\}$, deniz seviyesi değerleri $\{97.1798,97.6546,97.6363, \ldots, 102.4771\}$ olsun. Verilere ait deneysel birikimli dağılımların modellenmesi için Weibull dağılımı seçilmiş olsun. Weibull dağılımına ait tahmin edilmesi gereken parametreler A (Ölçek) ve B (Şekil) parametreleridir. Zaman verilerinin deneysel birikimli dağılımını modelleyecek Weibull dağılımına ait parametreler maksimum olabilirlik tahmin yöntemi kullanılarak $\mathrm{A}=$ 83.6023 ve $\mathrm{B}=1.6558$ olarak bulunur. Deniz seviyesi verilerinin deneysel birikimli dağılımlarını modellemek için ise maksimum olabilirlik yöntemi kullanılarak Weibull Dağılımına ait A ve B parametreleri sırasıly 100.4398 ve 106.0450 olarak bulunur. Böylece zaman ve deniz seviyesi verilerine ait deneysel birikimli dağılımları modelleyecek teorik dağılımın parametreleri tahmin edilmiş olur. Deniz seviyesi ve zaman değişkenlerine ait teorik olasılıklar Weibull dağılımının birikimli dağılım formülü,

$$
p=F(x \mid a, b)=1-e^{-\left(\frac{x}{A}\right)^{B}}
$$

ile hesaplanır (Rinne 2008) (Şekil 6). Burada x seriye ait değerleri, A dağılıma ait ölçek parametresini, B ise dağılıma ait şekil parametresini göstermektedir. p ise birikimli olasılık değerleridir. 

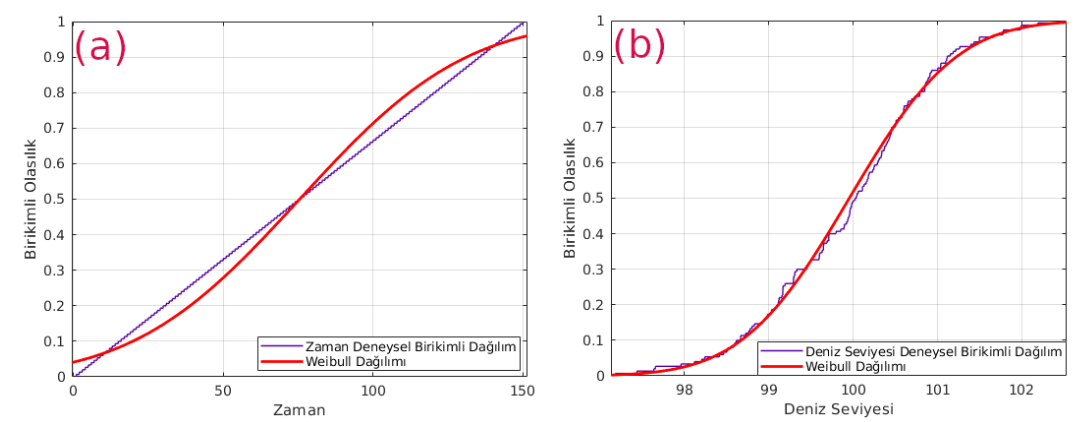

Şekil 6: Deniz Seviyesi ve Zaman verilerinin marjinal dağılımlarının modellenmesi (a - Zaman, b- Deniz Seviyesi)

(22)'de verilen formülden zaman değerlerine ait birikimli olasılıklar sırasıyla $\{0.7227,0.7256,0.7255, \ldots, 0.7536\}$ olarak bulunur. Değişkenler arasındaki ilişkiyi en iyi yansıtan kapula fonksiyonu Frank kapulası olarak seçilmiş olsun. Burada 2.3 bölümünde verilen maksimum olabilirlik yöntemine göre kapula parametresi hesaplanırsa $\theta=18.0673$ olarak bulunur. (17)'de verilen Frank kapula fonksiyonuna ait koşullu kapula fonksiyonunda; u yerine zaman verilerinin birikimli olasılık değerleri konulursa ve $\mathrm{v}=0.5$ olarak seçilirse kapula temelli birikimli deniz seviyesi trend olasıllkları $\{0.0401,0.0435$, $0.0473, \ldots, 0.9599$ \}olarak bulunur. Trend olasılıkları Weibull birikimli dağılım formülü (14)'ün ters fonksiyonu,

$$
x=-A[\ln (1-p)]^{1 / B}
$$

ile trend değerlerine dönüştürülür. Burada A Weibull dağılımına ait ölçek parametresini, B şekil parametresini göstermektedir. p ise trend olasılık değerleridir. (23)'ten deniz seviyesi kapula temelli trend değerleri \{98.2024, 98.2420, $98.2811, \ldots, 101.7032$ \} olarak bulunur (Şekil 7).

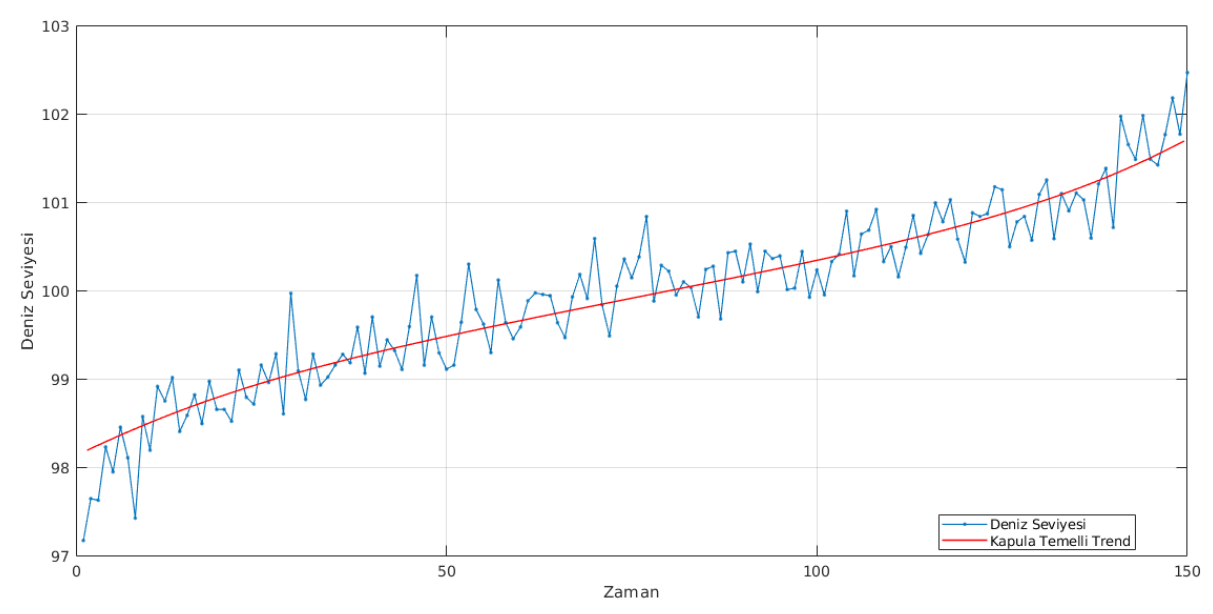

Şekil 7: Deniz seviyesi zaman serisi ve kapula temelli trend

\section{Sayısal Uygulama}

Ege Denizi'nde bulunan 5 mareograf istasyonunda (Thessaloniki, Alexandroupolis, Khilos, Menteş, Bodrum) 1990 2008 yılları arasında kaydedilen aylık ortalama deniz seviyesi verileri ile Ege Denizi’nin uzun dönemli deniz seviyesi değişimleri kapula temelli trend analiz yöntemi kullanılarak incelenmiştir (Şekil 8). İlk olarak deniz seviyesi ve zaman değişkenlerine ait dağılımlar teorik bir dağılım fonksiyonu kullanılarak modellenmiş, Clayton, Frank ve Gumbel kapula fonksiyonlarına ait kapula parametreleri hesaplanmıştır. Ardından her istasyondaki deneysel kapulalar hesaplanmış ve uyum iyiliği testi ile istasyonlardaki deniz seviyesi - zaman arasındaki ilişkiyi en iyi modelleyecek kapula fonksiyonları seçilmiştir. Seçilen teorik kapula fonksiyonlarının koşullu dağılımları ile kapula temelli trend analizleri yapılmıştır. 


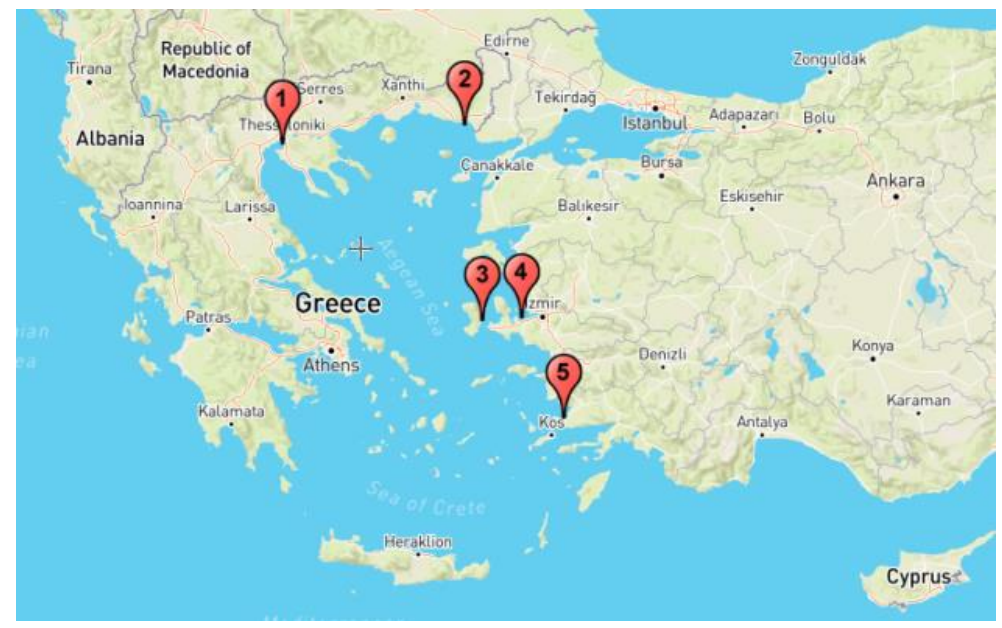

Şekil 8: Çalışmada kullanılan mareograf istasyonları

\subsection{Marjinal Dağılımların Modellenmesi}

İstasyonlardaki deniz seviyesi ve zaman değişkenlerine ait deneysel birikimli dağılımların teorik bir dağılım fonksiyonu ile modellenmesi amaciyla Normal dağılım, Logistik dağılım, Genelleştirilmiş Ekstrem dağılımı ve Weibull dağılımı kullanılmıştır. Teorik olasılıklar ve deneysel olasılıklar arasındaki farklardan karesel ortalama hata metriği (RMSE) hesaplanır. Değişkenlerin deneysel birikimli dağılımı ile teorik dağılımlar arasındaki farkın en küçük olduğu dağılım fonksiyonu en iyi dağılım fonksiyonu olarak seçilir (Tablo1).

Tablo 1: Değişkenlere ait deneysel birikimli dağılımların teorik bir dağııma uydurulması

\begin{tabular}{llll}
\hline İstasyon Adı & Dağılımlar & $\begin{array}{l}\text { RMSE } \\
\text { Zaman }\end{array}$ & $\begin{array}{l}\text { RMSE } \\
\text { Deniz Seviyesi }\end{array}$ \\
\hline Thessaloniki & Genelleştirilmiş Ekstrem & $\mathbf{0 . 0 4 6}$ & $\mathbf{0 . 0 4 6}$ \\
& Logistik & 0.048 & 0.048 \\
& Normal & 0.048 & 0.048 \\
& Weibull & 0.047 & 0.047 \\
\hline Alexandroupolis & Genelleştirilmiş Ekstrem & 0.040 & $\mathbf{0 . 0 4 6}$ \\
& Logistik & 0.036 & 0.048 \\
& Normal & $\mathbf{0 . 0 3 5}$ & 0.048 \\
\hline Khilos & Weibull & 0.055 & 0.047 \\
& Genelleştirilmiş Ekstrem & 0.050 & $\mathbf{0 . 0 4 6}$ \\
& Logistik & 0.043 & 0.047 \\
& Normal & $\mathbf{0 . 0 4 2}$ & 0.047 \\
& Weibull & 0.061 & 0.046 \\
\hline Mentes & Genelleştirilmiş Ekstrem & 0.039 & $\mathbf{0 . 0 4 7}$ \\
& Logistik & 0.040 & 0.048 \\
& Normal & $\mathbf{0 . 0 3 8}$ & 0.049 \\
& Weibull & 0.047 & 0.048 \\
\hline Bodrum & Genelleştirilmiş Ekstrem & $\mathbf{0 . 0 2 5}$ & $\mathbf{0 . 0 4 6}$ \\
& Logistik & 0.035 & 0.048 \\
& Normal & 0.037 & 0.047 \\
\hline & Weibull & 0.029 & 0.047 \\
\hline
\end{tabular}

Tablo 1'de görüldüğü gibi değişkenlere ait deneysel birikimli dağılımlar teorik dağılım fonksiyonlarına uydurulmuştur. Deneysel birikimli dağılıma en uygun teorik dağılımlar kırmızı renk ile gösterilmiştir. Tablo 1 incelendiğinde istasyonlardaki zaman verileri genellikle Normal Dağılıma, deniz seviyesi verileri ise Genelleştirilmiş Ekstrem Dağılımına uymaktadır. Khilos istasyonunda deniz seviyesi verileri için Genelleştirilmiş Ekstrem ve Weibull dağılımları aynı sonuçları verse de istasyonlardaki deniz seviyesi verilerinin genellikle genelleştirilmiş ekstrem dağılımına uyması nedeniyle genelleştirilmiş ekstrem dağılımı ile modellenmiştir.

\subsection{Deneysel Kapulanın Elde Edilmesi}

İstasyonlardaki zaman serilerinde bağımlılığı tamamen yansıtan deneysel kapulalar (8)'de verildiği gibi elde edilmiştir. Elde edilen deneysel kapulalar Şekil 9'da verilmiştir. 
Veri Sayısı
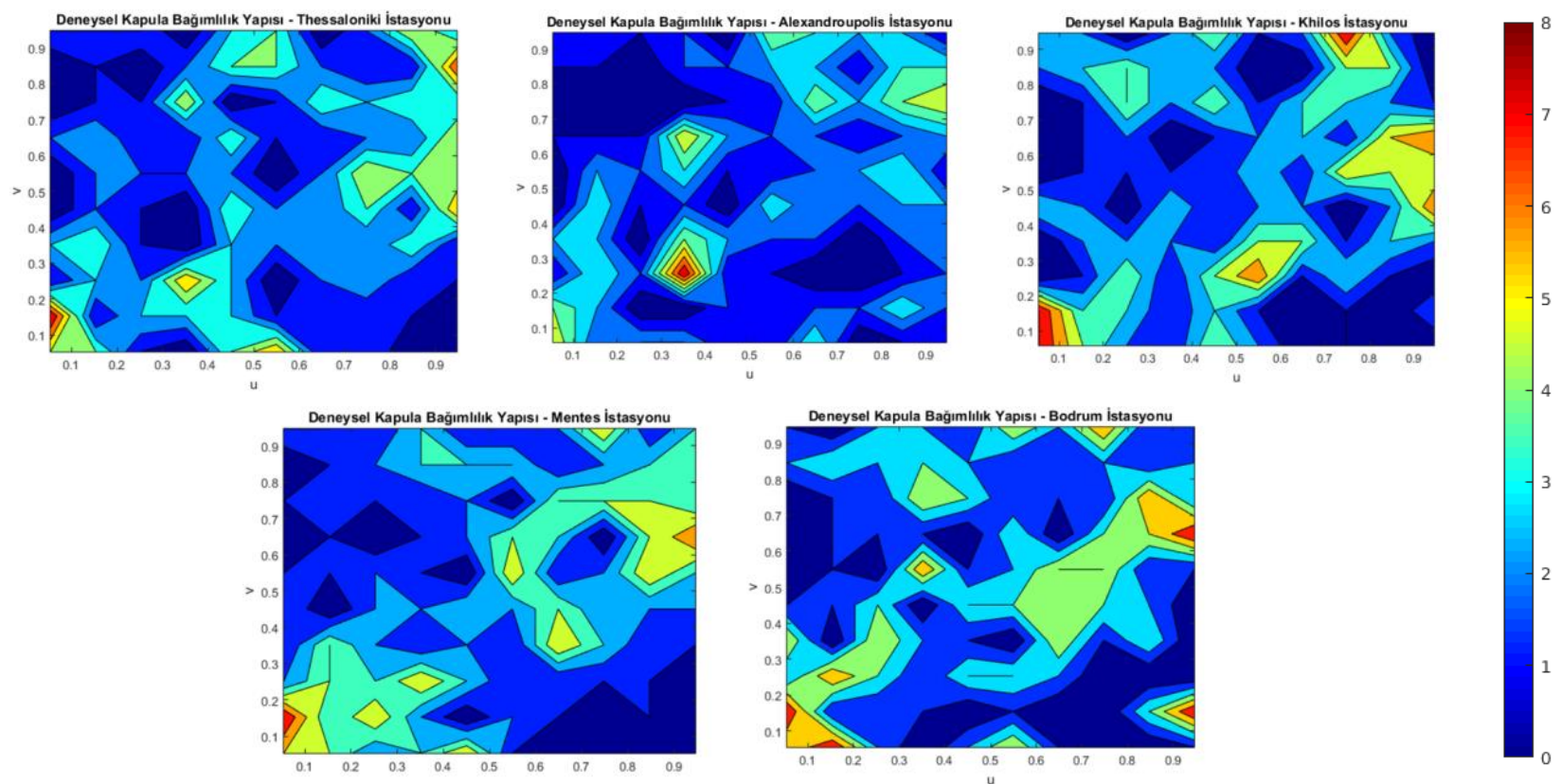

Şekil 9: İstasyonlardaki deneysel kapulalar

Şekil 9 incelenecek olursa deniz seviyesi ve zaman değişkenleri arasındaki ilişkinin sadece doğrusal olmadığı ve oldukça karmaşık bir yapıda olduğu söylenebilir. Ayrıca tüm istasyonlarda deneysel kapulalarda alt kuyrukta (sol alt köşe) verilerin yoğunlaştığı ve alt kuyrukta yüksek bağımlılığın olduğu görülmektedir. Yine tüm istasyonlara ait deneysel kapulalarda verilerin genellikle $\mathrm{y}=\mathrm{x}$ diagonali üzerinde yoğunlaştı̆̆ 1 ve dolayısıyla tüm istasyonlarda deniz seviyesi ve zaman arasında pozitif yönde bir korelasyonun olduğu söylenebilir.

\subsection{Kapula Parametresinin Tahmin Edilmesi}

İstasyonlardaki deniz seviyesi zaman serilerinin Clayton, Frank, Gumbel kapula fonksiyonları ile modellenebilmesi amacıyla kapula parametreleri maksimum olabilirlik yöntemine göre belirlenmiştir. Elde edilen kapula parametreleri ile deneysel kapulalar arasındaki farkı en küçük yapan kapula fonksiyonu en uygun kapula fonksiyonu olarak seçilmiştir. Fark istatistiği olarak Cramer - Von Mises Metriği kullanılmıştır (Tablo 2).

Tablo 2: Istasyonlarda elde edilen kapula parametreleri ve en uygun kapula fonksiyonları

\begin{tabular}{llll}
\hline İstasyon Adı & Kapula & Kapula Parametresi & Cramer Von Mises Metriği \\
& Fonksiyonu & & \\
\hline Thessaloniki & Frank & 2.0684 & 0.1168 \\
& Clayton & $\mathbf{0 . 5 3 6 3}$ & $\mathbf{0 . 0 6 9 6}$ \\
& Gumbel & 1.2073 & 0.2125 \\
\hline Alexandroupolis & Frank & 2.0437 & 0.1120 \\
& Clayton & $\mathbf{0 . 5 7 7 1}$ & $\mathbf{0 . 0 8 1 2}$ \\
& Gumbel & 1.1808 & 0.2283 \\
\hline Khilos & Frank & 1.6601 & 0.2984 \\
& Clayton & $\mathbf{0 . 5 7 6 5}$ & $\mathbf{0 . 1 1 1 8}$ \\
& Gumbel & 1.0956 & 0.5809 \\
\hline Mentes & Frank & 2.7410 & 0.1098 \\
& Clayton & $\mathbf{0 . 6 7 0 7}$ & $\mathbf{0 . 0 9 8 9}$ \\
& Gumbel & 1.2878 & 0.3504 \\
\hline Bodrum & Frank & 1.7435 & 0.1327 \\
& Clayton & $\mathbf{0 . 4 3 3 2}$ & $\mathbf{0 . 0 4 3 9}$ \\
& Gumbel & 1.1416 & 0.2837 \\
\hline
\end{tabular}

Tablo 2'de görüldüğü gibi istasyonlarda elde edilen kapula parametreleri ile en uygun kapula fonksiyonları seçilmiştir. İstasyonlardaki bağımlılık yapısına en uygun kapula fonksiyonları kırmızı renk ile gösterilmiştir. 


\subsection{Deniz Seviyesi Zaman Serilerinde Kapula Temelli Trend Analizleri}

İstasyonlardaki deniz seviyesi ve zaman değişkenlerine ait dağı̆lımların modellenmesi ve bağımlılık yapısına en uygun kapula fonksiyonlarının seçilmesinin ardından bağımlılıkların modellenmesi tamamlanmıştır. Modellenen bağımlılıklara ait kapula fonksiyonlarının koşullu dağılımları kullanılarak deniz seviyesi zaman serilerinde kapula temelli trend analizleri yapılmıştır. Elde edilen trendler Şekil 10'da verilmiştir.
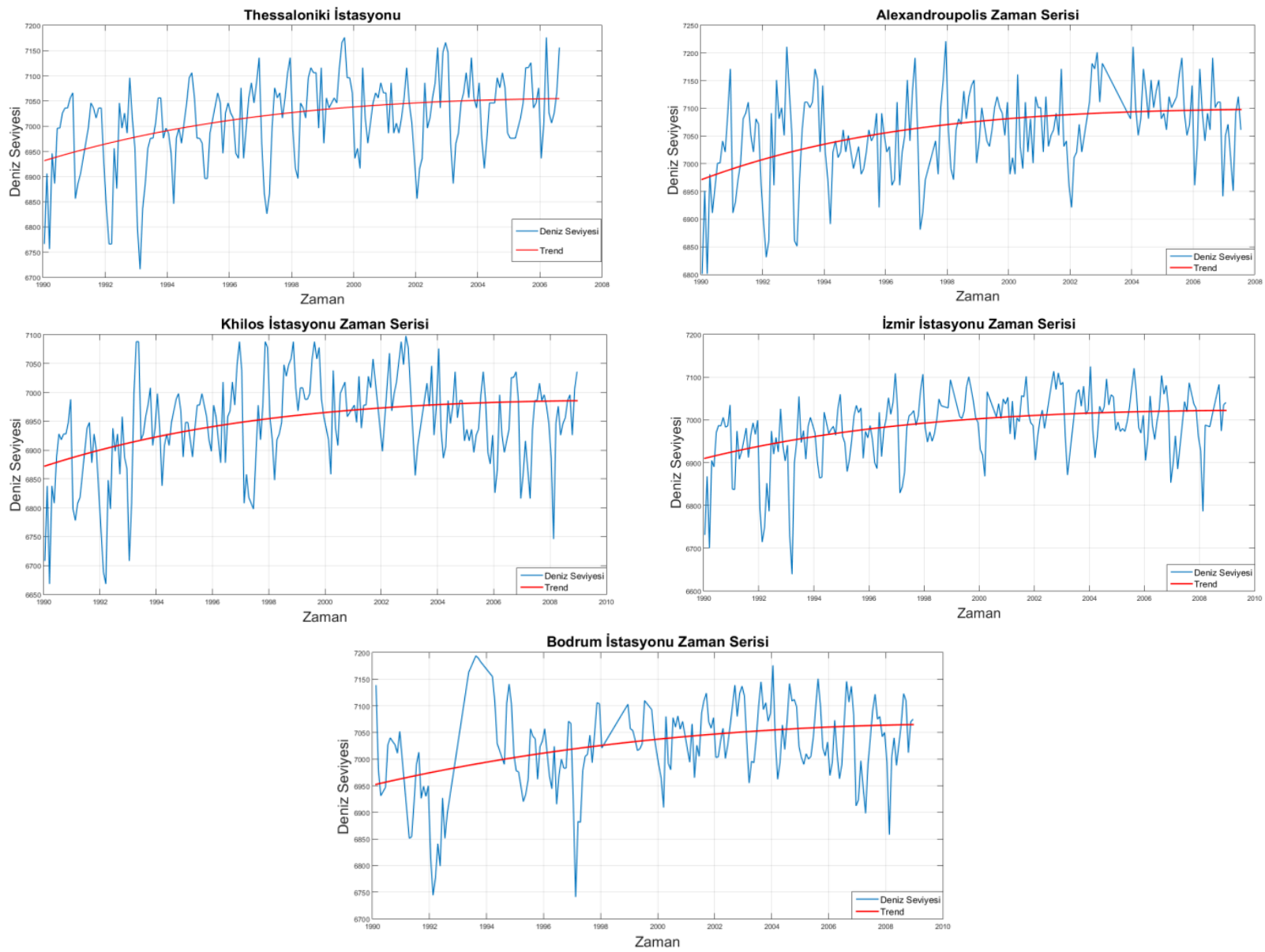

Şekil 10: Deniz seviyesi zaman serilerinde kapula temelli trend analizleri

Yapılan trend analizi sonucunda 1990-2008 yılları arasında elde edilen yıllık deniz seviyesi değişim hızları Tablo 3'de verilmiştir.

Tablo 3: 1990-2008 arasındaki yıllık deniz seviyesi değişim hızları

\begin{tabular}{ll}
\hline İstasyon Adı & $\begin{array}{l}\text { Yıllık Deniz Seviyesi } \\
\text { Değişim Hızı(mm/yıl) }\end{array}$ \\
\hline Thessaloniki & $5.84 \pm 1.1$ \\
Alexandroupolis & $5.95 \pm 1.3$ \\
Khilos & $5.89 \pm 1.9$ \\
Menteş & $5.78 \pm 1.5$ \\
Bodrum & $5.79 \pm 1.8$ \\
\hline
\end{tabular}

İstasyonlarda yapılan kapula temelli trend analizlerinde tüm istasyonlarda zaman serilerinin erken dönemlerinde daha yüksek deniz seviyesi değişim hızları elde edilmiş, bu hızların zaman serisi ilerledikçe düştükleri gözlemlenmiş̧ir. Bunun üzerine istasyonlarda 1990-2008 tarihleri arasındaki aylık ortalamalı deniz seviyesi zaman serileri, deniz seviyesi artı̧̧ trendinin daha yüksek olduğu 1990-1998 (1. Dönem) ve deniz seviyesi artış trendinin düştüğü 1999-2008 (2. Dönem) olmak üzere iki dönemde kapula temelli trend analizi ile incelenmiştir. Böylece deniz seviyesi trendlerinde oluşan farklılığın daha iyi incelenebilmesi amaçlanmıştır. 


\subsection{Deniz Seviyesi Zaman Serilerinin İki Dönemde Kapula Temelli Trend Analizleri}

Ege Denizi'nde bulunan mareograf istasyonlarından elde edilen deniz seviyesi zaman serileri 1990-1998 (1. Dönem) ve 1999-2008 (2. Dönem) olmak üzere iki döneme ayrılmıştır. Tüm dönemlere ait marjinal dağılımlar modellenmiş, deneysel kapulalar hesaplanmış ve teorik kapula parametreleri hesaplanarak en uygun kapula fonksiyonları seçilmiştir. Tüm dönemlerde deniz seviyesi zaman serilerine ait bağımlılıkları en iyi modelleyecek kapula fonksiyonu Frank kapula fonksiyonu olarak bulunmuştur. Yapılan kapula temelli trend analizleri sonucunda zaman serilerinde elde edilen trendler Şekil $11^{\prime}$ de verilmiştir.
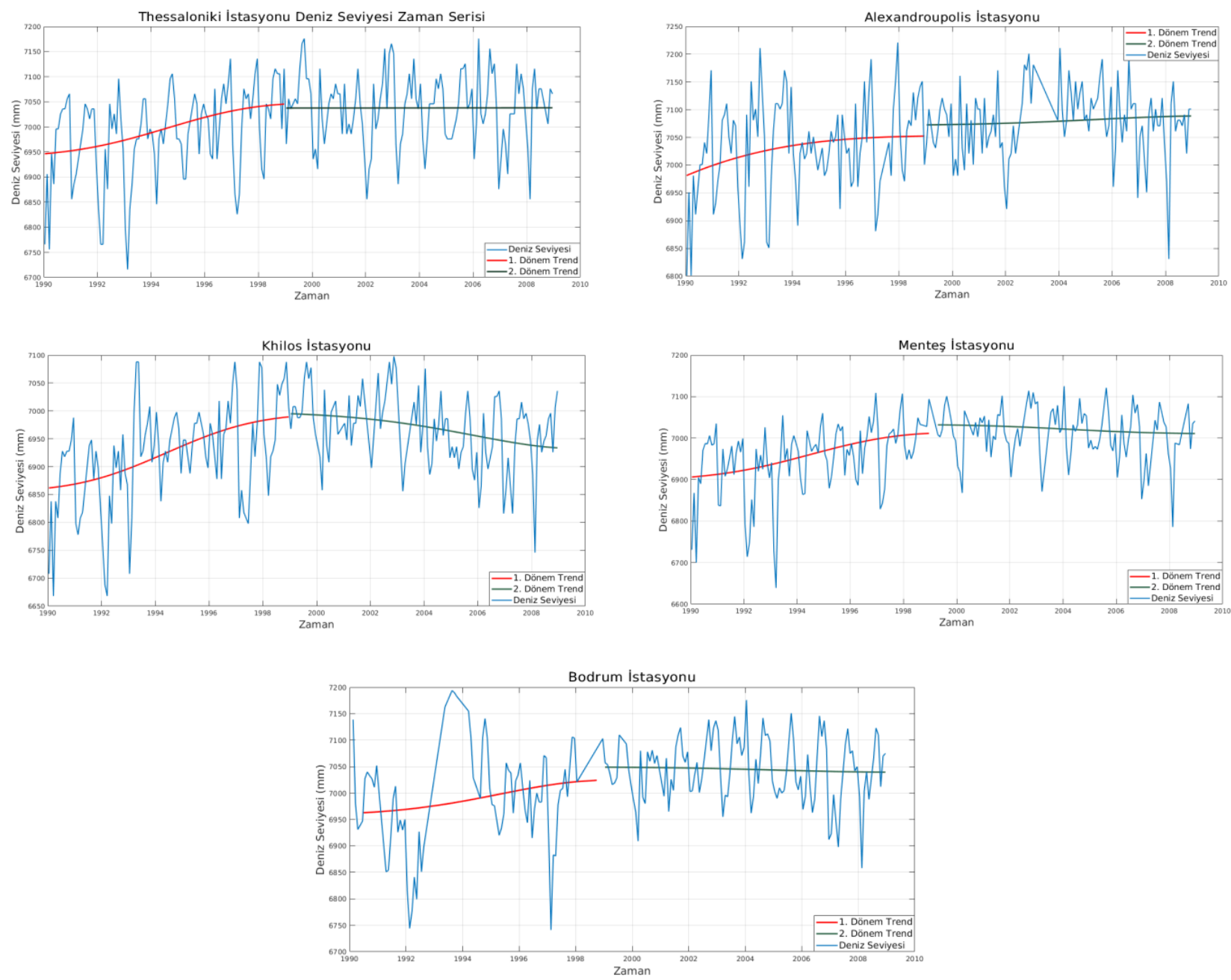

Şekil 11: Deniz seviyesi zaman serilerinde iki dönemli kapula temelli trend analizleri

Şekil 11'de verilen iki dönemli kapula temelli trend analizi sonucunda istasyonlarda elde edilen birinci ve ikinci dönemlere ait deniz seviyesi değişim hızları Tablo 4'te verilmiştir.

Tablo 4: Ege Denizi'nde iki dönemli deniz seviyesi değişim hızları

\begin{tabular}{lll}
\hline İstasyon Adı & 1.Dönem $(\mathbf{m m} / \mathbf{y ı l})$ & 2.Dönem $(\mathbf{m m} / \mathbf{y ı l})$ \\
\hline Thessaloniki & $10.89 \pm 3.1$ & $0.01 \pm 1.1$ \\
Alexandroupolis & $7.89 \pm 3.3$ & $1.6 \pm 0.8$ \\
Khilos & $14.11 \pm 4.2$ & $-6.1 \pm 2.4$ \\
Menteş & $11.3 \pm 2.5$ & $-2.1 \pm 1.3$ \\
Bodrum & $6.78 \pm 3.6$ & $-0.9 \pm 1.3$ \\
\hline
\end{tabular}

Tablo 4 incelendiğinde birinci dönemde oldukça yüksek olan deniz seviyesi artış hızları ikinci dönemde oldukça azalmış ve bazı istasyonlarda işaret değiştirmiştir. 
Bu deniz seviyesi değişimlerinin nedeni olabileceği düşünülen deniz yüzey sıcaklığı zaman serileri 1990-1998 (1.Dönem) ve 1999-2008 (2. Dönem) olmak üzere iki farklı dönemde kapula temelli trend analiz yöntemi kullanılarak incelenmiştir.

\subsection{Deniz Yüzey Sıcaklığı Zaman Serilerinin İki Dönemde Kapula Temelli Trend Analizleri}

Ege Denizi’nde birinci ve ikinci dönemde deniz seviyelerinde meydana gelen farklılığın sebebi olabileceği düşünülen Gelişmiş Çok Yüksek Çözünürlüklü Radyometre ve yersel deniz yüzey sıcaklığı ölçümlerinin birleşiminden elde edilen deniz yüzey sıcaklığı zaman serileri 1990-1998 (1. Dönem) ve 1999-2008 (2. Dönem) olarak iki dönemde incelenmiştir. Tüm dönemlere ait marjinal dağılımlar modellenmiş, deneysel kapulalar hesaplanmış ve teorik kapula parametreleri hesaplanarak en uygun kapula fonksiyonları seçilmiştir. Yapılan kapula temelli trend analizleri sonucunda zaman serilerinde elde edilen trendler Şekil $12^{`}$ de verilmiştir.
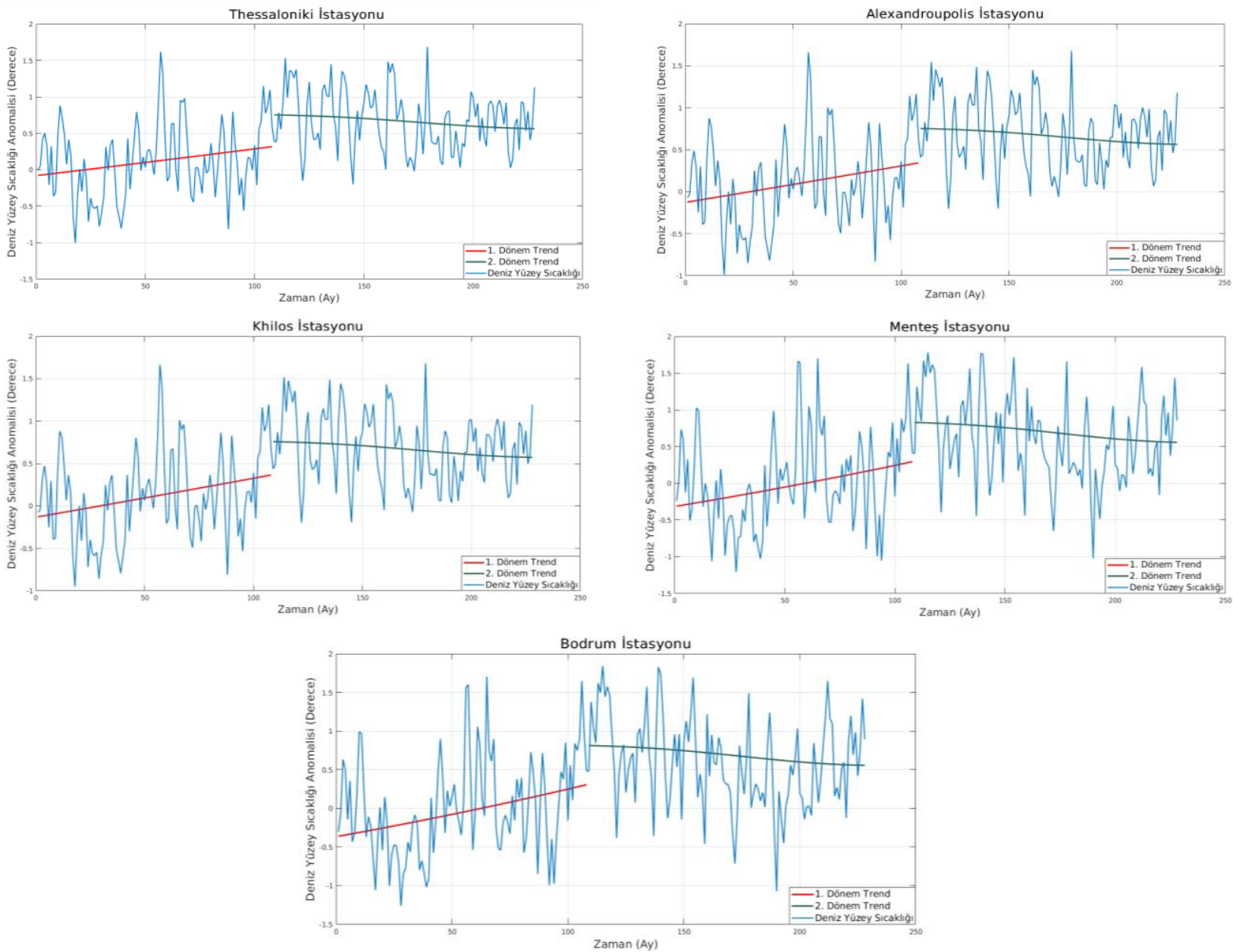

Şekil 12: Deniz yüzey sıcaklığı zaman serilerinde iki dönemli kapula temelli trend analizleri

Şekil 12'de görüldüğü gibi deniz yüzey sıcaklıkları 1. Dönemde tüm istasyonlarda artış trendi gösterirken 2. Dönemde ise deniz yüzey sıcaklığı trendlerinin yön değiştirerek negatif yönde azalan hız yapısına sahip olduğu görülmektedir. Deniz yüzey sıcaklıklarına ait yıllık hızlar Tablo 5'te verilmiştir.

Tablo 5: Deniz yüzey sıcaklığı zaman serilerinde iki dönemde yıllık hız değerleri

\begin{tabular}{lll}
\hline İstasyon Adı & 1.Dönem $\left({ }^{\circ} \mathbf{C} /\right.$ Yıl $)$ & 2.Dönem $\left({ }^{\circ} \mathbf{C} /\right.$ Yıl $)$ \\
\hline Thessaloniki & $0.044 \pm 0.01$ & $-0.019 \pm 0.01$ \\
Alexandroupolis & $0.052 \pm 0.02$ & $-0.021 \pm 0.01$ \\
Khilos & $0.055 \pm 0.02$ & $-0.020 \pm 0.01$ \\
Menteş & $0.067 \pm 0.03$ & $-0.027 \pm 0.01$ \\
Bodrum & $0.074 \pm 0.03$ & $-0.026 \pm 0.01$ \\
\hline
\end{tabular}


Tablo 5'te görüldüğü gibi tüm mareograf istasyon bölgelerindeki 1. Dönemde artan deniz yüzey sicaklıklarının 2 . Dönemde azaldığı görülmektedir.

\subsection{Kapula Temelli Trend Analizinin Regresyon Analizi ile Karşılaştırılması}

Bu bölümde kapula temelli trend analiz yönteminin uygulanabilirliğini test etmek amaciyla regresyon analizinden üretilen trend modelleri kullanılmıştır. Kapula temelli trend modelleri birinci ve ikinci dereceden regresyon modelleri ile karşılaştırılarak sonuçları irdelenmiştir. Thessaloniki, Alexandroupolis, Khilos, Menteş ve Bodrum İstasyonlarına ait tüm dönem (1990 - 2008) deniz seviyesi zaman serilerinde lineer regresyon analizi uygulanmıştır. Lineer regresyona ait doğru denklemi,

$$
Y_{i}+v_{i}=a_{0}+a_{1} X_{i}
$$

şeklinde ifade edilmiştir. Burada $a_{0}$ katsayısı doğrunun y ekseninde kestiği noktayı ve $a_{1}$ katsayısı ise doğrunun eğimini göstermektedir. $v_{i}$ regresyon modeline ait düzeltme değerleri, $X_{i}$ bağımsız değişken, $Y_{i}$ ise bağımlı değişken değerini göstermektedir. Lineer regresyon analizi sonucunda $T$ testine göre katsayıların anlamlı çıkması durumunda ikinci dereceden regresyon analizi uygulanmıştır. Uygulanan lineer regresyon analizi sonucunda elde edilen değerler Tablo 6`da verilmiştir.

Tablo 6: Deniz seviyesi zaman serilerinde lineer regresyon katsayıları

\begin{tabular}{lll}
\hline İstasyon Adı & $a_{0}$ Katsayısı & $a_{1}$ Katsayısı \\
\hline Thessaloniki & -4183.5462 & 5.5992 \\
Alexandroupolis & -2179.9767 & 4.6194 \\
Khilos & -1820.0997 & 4.3832 \\
Menteş & -5445.7165 & 6.2156 \\
Bodrum & -2081.0292 & 4.5515 \\
\hline
\end{tabular}

Uygulanan regresyon analizleri sonucunda elde edilen katsayıların anlamlılığ $1 \mathrm{~T}$ testi ile test edilmiştir. $H_{0}$ hipotezi regresyon katsayısının anlamsız olduğunu, $H_{1}$ hipotezi regresyon katsayısının anlamlı olduğunu göstermek üzere \%95 güven aralığında katsayılara ait anlamlılık testi T Testi kullanılarak elde edilir. Katsayılara ait test büyüklükleri,

$$
\begin{aligned}
& T_{0}=\frac{\left|a_{0}\right|}{m_{a_{0}}} \\
& T_{1}=\frac{\left|a_{1}\right|}{m_{a_{1}}}
\end{aligned}
$$

Formülleri ile elde edilir. T testi için gerekli tablo değeri $\alpha$ yanılma olasılığında $n$-u serbestlik derecesinde T tablosundan,

$$
t=t_{n-u, 1-\frac{\alpha}{2}}
$$

olarak elde edilir. Test büyüklüğü ve tablo değerlerinin karşılaştırılması ile, $T<t$ ise $H_{0}$ hipotezi kabul edilir. $T>t$ ise $H_{1}$ hipotezi kabul edilir. \%95 güven aralığında katsayılara ait anlamlılık testi sonuçları Tablo 7‘de verilmiştir.

Tablo 7: Lineer regresyon katsayıları anlamlılı testi

\begin{tabular}{llllll}
\hline \multirow{2}{*}{ İstasyon Adı } & $\begin{array}{l}a_{0} \\
\text { Katsayısı } \\
\text { Test } \\
\text { Büyüklüğüu }\end{array}$ & $\begin{array}{l}a_{1} \\
\text { Katsayısı } \\
\text { Test } \\
\text { Büyüklüğü }\end{array}$ & $\begin{array}{l}\text { Tablo } \\
\text { Değeri }\end{array}$ & $\begin{array}{l}a_{0} \\
\text { Katsayısı } \\
\text { Sonucu }\end{array}$ & $\begin{array}{l}a_{1} \\
\text { Katsayısı } \\
\text { Sonucu }\end{array}$ \\
\hline Thessaloniki & 2.1578 & 5.7751 & 1.9708 & Anlamlı & Anlamlı \\
Alexandroupolis & 1.1868 & 5.0283 & 1.9712 & Anlamsız & Anlamlı \\
Khilos & 0.9438 & 4.5445 & 1.9714 & Anlamsız & Anlamlı \\
Menteş & 2.9005 & 6.6188 & 1.9714 & Anlamlı & Anlamlı \\
Bodrum & 1.0053 & 4.3981 & 1.9725 & Anlamsız & Anlamlı \\
\hline
\end{tabular}

Tablo 7' de görüldüğü gibi lineer regresyon analizinden elde edilen $a_{1}$ katsayılarının tamamı \%95 güven aralığında anlamlıdır. Yani deniz seviyesi zaman serilerinin tamamında artan yönde bir trend mevcuttur. 
Tüm istasyon verilerinde lineer regresyon analizi sonucunda anlamlı bir artış trendi elde edilmesinin ardından 2. Derece regresyon analizi uygulanmıştır. İkinci derece regresyon denklemi,

$$
Y+V=a_{0}+a_{1} X+a_{2} X^{2}
$$

şeklinde kurulmuştur. $v_{i}$ regresyon modeline ait düzeltme değerleri, $X_{i}$ bağımsız değişken, $Y_{i}$ ise bağımlı değişken değerini, $a$ ise katsayıları göstermektedir. Deniz seviyesi zaman serilerinde yapılan 2. Derece regresyon analizi katsayıları Tablo 8‘de verilmiştir.

Tablo 8: Ikinci Derece regresyon analizi katsayıları

\begin{tabular}{llll}
\hline İstasyon Adı & $a_{0}$ Katsayısı & $a_{1}$ Katsayısı & $a_{2}$ Katsayısı \\
\hline Thessaloniki & -2532938.0954 & 2535.1135 & -0.6325 \\
Alexandroupolis & -1995486.5000 & 1998.3729 & -0.4985 \\
Khilos & -4953156.4062 & 4956.8845 & -1.2384 \\
Menteş & -3414904.3437 & 3416.8296 & -0.8529 \\
Bodrum & -2020938.4687 & 2023.7177 & -0.5048 \\
\hline
\end{tabular}

Tablo 8'de verilen 2. Derece regresyon katsayılarının T testine göre anlamlılıkları araştırılmıştır. Elde edilen sonuçlar Tablo 9'da verilmiştir.

Tablo 9: Ikinci Derece regresyon katsayılarının anlamlılığı testi

\begin{tabular}{lllll}
\hline İstasyon Adı & $\begin{array}{l}a_{0} \text { Katsayısı } \\
\text { Test } \\
\text { Büyüklüğü }\end{array}$ & $\begin{array}{l}a_{1} \text { Katsayısı } \\
\text { Test } \\
\text { Büyüklüğü }\end{array}$ & $\begin{array}{l}a_{2} \text { Katsayısı } \\
\text { Test } \\
\text { Büyüklüğü }\end{array}$ & $\begin{array}{l}\text { Tablo } \\
\text { Değeri }\end{array}$ \\
\hline Thessaloniki & 3.2570 & 3.2588 & 3.2516 & 1.9708 \\
Alexandroupolis & 2.7042 & 2.7075 & 2.7013 & 1.9713 \\
Khilos & 6.8365 & 6.8401 & 6.8340 & 1.9714 \\
Menteş & 4.5825 & 4.5835 & 4.5752 & 1.9715 \\
Bodrum & 2.4448 & 2.4447 & 2.4423 & 1.9726 \\
\hline
\end{tabular}

Tablo 9'da elde edilen test büyüklükleri ve tablo değerleri incelendiğinde tüm katsayılara ait test büyüklüklerinin tablo değerlerinden büyük çıkması nedeniyle $H_{1}$ hipotezi kabul edilir. Yani tüm istasyonlarda elde edilen 2. Derece regresyon katsayıları anlamlıdır. Deniz seviyesi zaman serilerinin tüm döneminde yapılan 2. Derece regresyon analizi ile kapula temelli trend analiz yöntemleri grafik üzerinden karşılaştırılmıştır (Şekil13).

Şekil 13 incelendiğinde kapula temelli trend eğrisi ile regresyon eğrisi arasındaki fark genellikle zaman serilerinin son dönemlerinde ve trend negatif yöne doğru eğilim gösterdiğinde ortaya çıkmaktadır. Bu durum istasyonlardaki tüm dönem deniz seviyesi zaman serilerinde en uygun kapula fonksiyonu olarak seçilen Clayton kapula fonksiyonunun negatif yöndeki bağımlılıkları modellemek için uygun fonksiyon yapısına sahip olmamasından kaynaklanmaktadır. Ayrıca 2. Derece regresyon eğrileriyle oldukça yakın olan kapula temelli trend eğrileri en fazla Khilos istasyonunda farklılık göstermiştir. Ancak kapula temelli trendler ile regresyon trendlerinin birbirine oldukça yakın sonuçlar verdiği görülmektedir. 

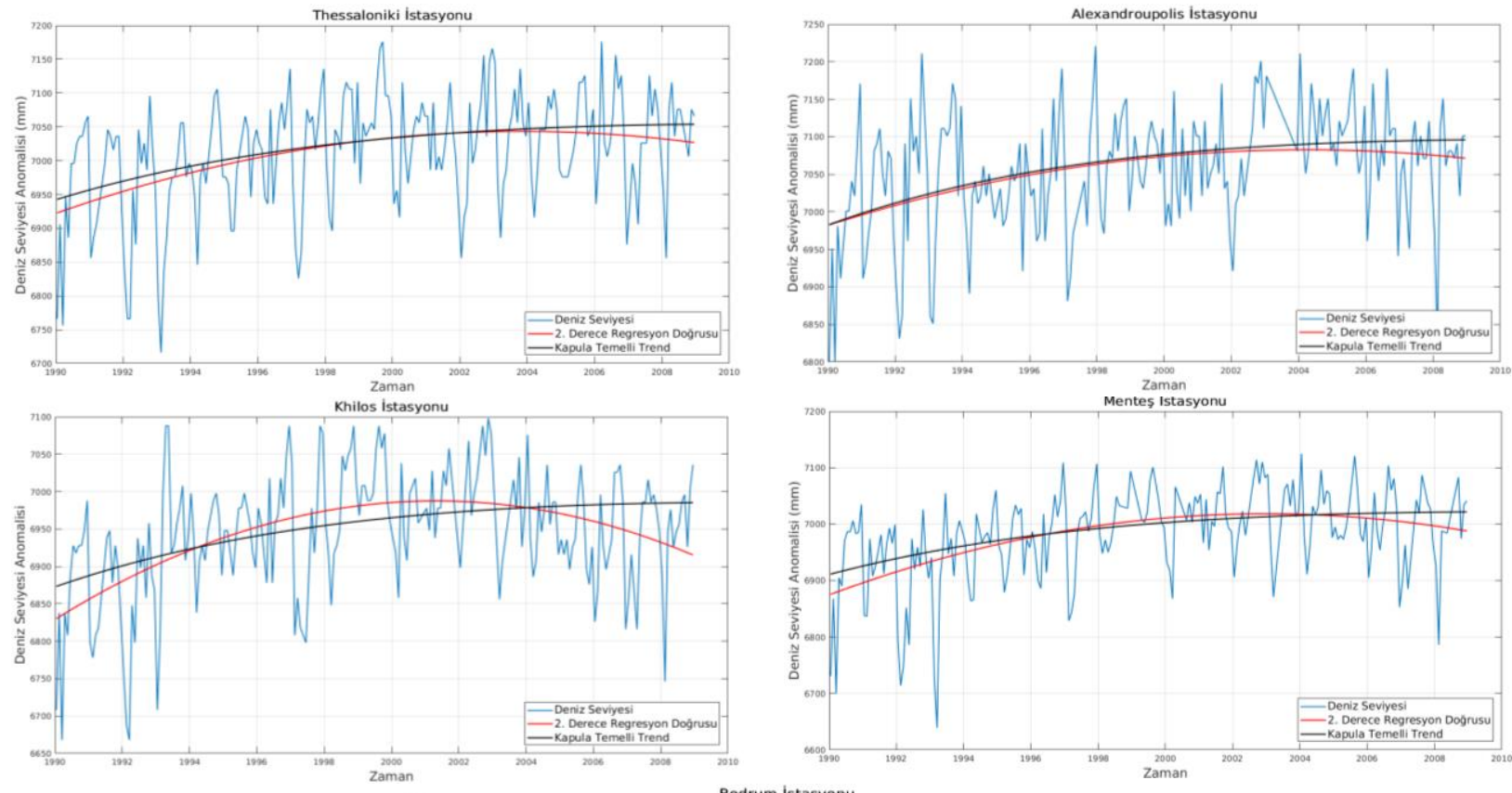

Bodrum istasyon

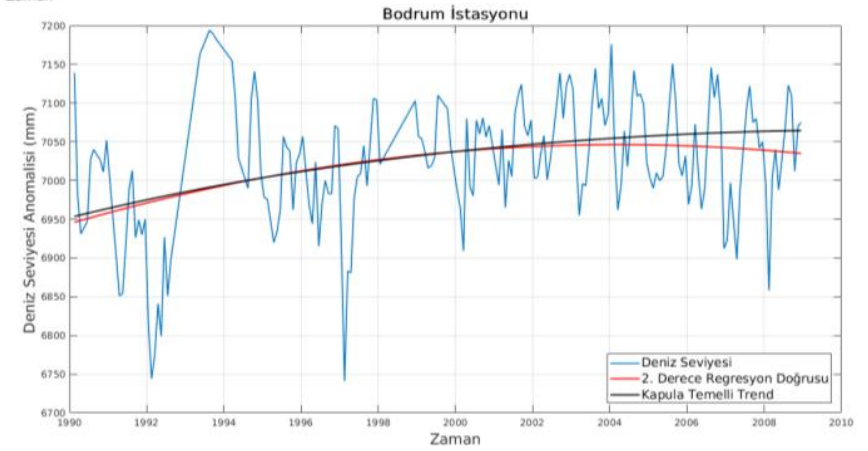

Şekil 13: Kapula temelli trendler ve regresyon eğrileri (kırmızı - regresyon eğrisi, siyah - kapula temelli trend)

\section{Sonuçlar}

Yapılan çalışmada Ege Denizi'nde bulunan 5 mareograf istasyonundan elde edilen bağıl deniz seviyesi değişimleri kapula fonksiyonları ile incelenmiştir. İlk olarak istasyonlardaki deniz seviyesi ve zaman değişkenlerine ait dağılımlar teorik dağılım fonksiyonları ile modellenmiş, istasyonlardaki ortak dağılımların deneysel kapulaları hesaplanmıştır. İstasyonlardaki deniz seviyesi zaman serilerinin bağımlılık yapısına en uygun teorik kapula fonksiyonları seçilmiş ve kapula parametreleri hesaplanmıştır. Elde edilen bağımlılık modelleri kullanılarak 1990-2008 aylık ortalamalı deniz seviyesi zaman serilerinde kapula temelli trend analizleri yapılmıştır. Yapılan trend analizleri sonucunda; deniz seviyesi zaman serilerinin erken dönemlerinde yüksek deniz seviyesi değişim hızları elde edilmiş, bu hızların zaman serisi ilerledikçe düştükleri gözlemlenmiştir. Bunun üzerine istasyonlarda 1990-2008 tarihleri arasındaki aylık ortalamalı deniz seviyesi zaman serileri, deniz seviyesi artış trendinin daha yüksek olduğu 1990-1998 (1. Dönem) ve deniz seviyesi artış trendinin düştüğü 1999-2008 (2. Dönem) olmak üzere iki dönemde kapula temelli trend analizi ile incelenmiştir. İki dönemli trend analizleri sonucunda 1. Dönemde tüm istasyonlarda Global deniz seviyesi değişim hızlarına göre oldukça yüksek deniz seviyesi artış hızları tespit edilmiş, bu artış hızlarının 2. Dönemde Khilos ve Menteş mareograf istasyonlarında yön değiştirdiği ve deniz seviyesinin azaldığı tespit edilmiştir. Thessaloniki mareograf istasyonunda 1. Dönem oldukça yüksek olan deniz seviyesi artış hızı 2. Dönemde sabit kalmış ve önemli bir değişim tespit edilememiştir. Alexandroupolis mareograf istasyonunda ise 1. Dönemde yüksek olan deniz seviyesi artış hızı, 2. Dönemde azalarak Global deniz seviyesi değişim hızlarına göre düşük bir hıza ulaşmıştır. Böylece tüm istasyonlarda deniz seviyesi 1 . Dönemde oldukça yüksek bir şekilde artarken 2. Dönemde artış miktarının azaldığı veya yön değiştirerek deniz seviyelerinde azalmaların meydana geldiği görülmüştür. Bu değişimlerin nedeni olabileceği düşünülen deniz yüzey sıcaklıkları 1990-1998 (1.Dönem) ve 1999-2008 (2. Dönem) olarak iki dönemde kapula fonksiyonları ile incelenmiştir. Deniz yüzey sıcaklıklarında yapılan kapula temelli trend analizleri sonucunda 1. Dönemde mareograf istasyonlarının bulunduğu bölgelerin tamamında deniz yüzey sıcaklıklarının arttığı, 2. Dönemde ise deniz yüzey sıcaklığı artışlarının yön değiştirdiği ve deniz yüzey sıcaklığında soğumaların meydana geldiği görülmüştür. 
Böylece Ege Denizi'nde 1990 - 1998 arasındaki dönemde meydana gelen yüksek deniz seviyesi artı̧̧ hızlarının deniz yüzey sıcaklıklarının artmasından kaynaklandığı, 1999 - 2008 arasındaki dönemde ise sabit kalan veya azalan deniz seviyesinin de deniz yüzey sıcaklıklarında meydana gelen soğumalardan kaynaklandığı değerlendirilmiştir. Ayrıca bu çalışmada ilk defa sunulan kapula temelli trend analiz yönteminin kullanılabilirliği regresyon analizleri ile karşılaştırılarak irdelenmiş ve regresyon analizlerine oldukça yakın sonuçlar verdiği görülmüştür. Böylece kapula temelli trend analiz yönteminin deniz seviyesi zaman serilerinde kullanılabileceği gösterilmiştir.

\section{Kaynaklar}

Bárdossy A., Li J., (2008), Geostatistical interpolation using copulas, Water Resources Research, Vol. 44, W07412, 1-15, doi:10.1029/2007WR006115.

Beşel C., Kayıkçı E.T., (2016), Meteorolojik verilerin zaman serisi ve tanımlayıcı istatistikler ile yorumlanması; Karadeniz Bölgesi örneği, Uluslararası Coğrafya Sempozyumu Bildiriler Kitabı'nın İçinde (Özçağlar A., Türkoğlu N., vd., Ed.), Ankara, Türkiye, ss.50-69.

Bingöl A., (2012), Kopula fonksiyonlarl ve bir uygulama, Doktora Tezi, Fırat Üniversitesi, Elazı̆̆.

Cazenave A., (2017), Global sea-level budget 1993-present, Earth System Science Data, 10, 1551-1590.

Cazenave A., Mercier F., Toumazou V., Bonnefond P., Dominh K., (2002), Sea level variations in the Mediterranean Sea and Black Sea from satellite altimetry and tide gauges, Global and Planetary Change, 34(1-2), 59-86.

Cazenave A., Cabanes C., Dominh K., Mangiarotti S., (2001), Recent sea level change in the Mediterranean Sea revealed by Topex/Poseidon satellite altimetry, Geophysical Research Letters, 28(8), 1607-1610.

Church J. A., White N.J., Coleman R., Lambeck K., Mitrovica J. X., (2004), Estimates of the regional distribution of sea level rise over the 1950-2000 period, Journal of Climate, 17(13), 2609-2625.

Çelebioğlu S., (2003), Arşimedyen kapulalar ve bir uygulama, Selçuk Üniversitesi Fen Fakültesi Fen Dergisi, 1(22), 43-52.

Demir E., (2018), Türkiye'nin iklim değişikliği ile mücadelede kullanabileceği iktisadi araçların değerlendirilmesi: Karbon vergileri ve emisyon ticaret sistemleri, Doktora Tezi, İstanbul Üniversitesi, İstanbul.

Genest C., Favre, A.C., (2007), Everything you always wanted to know about copula modeling but were afraid to ask, Journal of Hydrologic Engineering, 12(4), 347-368.

Hannah J., (1989), A longterm sea level change scenario and its implications for geodetic networks, Marine Geodesy, 13(2), 91-100.

Harris J. W., Stöcker H., (1998), Handbook of mathematics and computational science, Springer-Verlag, New York, USA, 1028 ss.

Hay C.C., Morrow E., Kopp R.E., Mitrovica, J.X., (2015), Probabilistic reanalysis of twentieth-century sea-level rise, Nature, 517(7535), 481-484.

Jevrejeva S., Moore J.C., Grinsted A., Matthews A.P., Spada G., (2014), Trends and acceleration in global and regional sea levels since 1807, Global and Planetary Change, 113, 11-22.

Joe H., (1997), Multivariate models and multivariate dependence concepts, Chapman and Hall/CRC, New York, USA, 424ss.

Laux P. vd. (2011). Copula-based statistical refinement of precipitation in RCM simulations over complex terrain. Hydrology and Earth System Sciences 15(7): 2401-2419.

Modiri S., (2015), Copula-based analysis of correlation structures in case of GRACE coefficients, Yüksek Lisans Tezi, University of Stuttgart, Stuttgart, Germany.

Nelsen R.B., (2007), An introduction to copulas, Springer-Verlag, Berlin, Germany, 270ss.

Özbakış Y.G., (2006), Bazı kapula tahmin yöntemleri ve bir uygulama, Yüksek Lisans Tezi, Gazi Üniversitesi, Ankara.

Rinne H., (2008), The Weibull distribution: a handbook. Chapman and Hall/CRC, New York, USA, 808ss.

Simav M., (2007), Doğu Akdeniz'de uydu altimetre verileri ile deniz seviyesi değişimlerinin araştırılması, Yüksek Lisans Tezi, İstanbul Teknik Üniversitesi, İstanbul.

Sklar M., (1959), Fonctions de repartition an dimensions et leurs marges, Publications de l'Institut Statistique de l'Université de Paris, 8, 229-231.

Topçu Ç., (2013), Yarışan bă̆ımlı risklerle sağkalım analizinde archimedean kapula yaklaşımı, Doktora Tezi, Ankara Üniversitesi, Ankara.

Tsimplis M.N., Baker T.F., (2000), Sea level drop in the Mediterranean Sea: an indicator of deep water salinity and temperature changes, Geophysical Research Letters, 27(12), 1731-1734.

Vogl S., Laux P., Qiu W., Mao G., Kunstmann H., (2012), Copula-based assimilation of radar and gauge information to derive bias corrected precipitation fields, Hydrology and Earth System Science, 16, 2311-2328.

Wang W., Wells M.T., (2000), Model selection and semiparametric inference for bivariate failure-time data, Journal of the American Statistical Association, 95(449), 62-72. 